\title{
Genetic Disorders Preventive Approach \& Its Management: An Ayurvedic Review
}

\author{
Dr. Smita V.Lokhande* ${ }^{* 1}$, Dr. R. B.Patil ${ }^{2}$, Dr. Swapnil S.Patil ${ }^{3}$ \\ ${ }^{* 1}$ Assistant Professor, Department of Kayachikitsa, Hon. Annasaheb Dange Ayurved Medical College \& \\ Research Center, Ashta, Tal.-Walwa, Dist.-Sangli \\ ${ }^{2}$ Assistant Professor, Department of Panchakarma, Hon. Annasaheb Dange Ayurved Medical College \& \\ Research Center, Ashta, Tal.- Walwa, Dist.- Sangli \\ ${ }^{3}$ Assistant Professor, Department of Rognidan evm V.V., Hon. Annasaheb Dange Ayurved Medical College \\ \& Research Center, Ashta, Tal.- Walwa, Dist.- Sangli
}

\begin{abstract}
:
The genetic disorders are the prime obstacles in the development of human being. The causative factors for these disorders are the improper formation of genotype. There are many causative factors for the derangement of genotype. Ayurvedic literature also stated about the genetic disorders as beejdosha vikara, \& also there is elaboration about clearance of beej dosha. Hence in present paper the topic has been discussed.
\end{abstract}

Keywords: - genetic disorder, beejdosha, vikara.

\section{INTRODUCTION:}

With increasing ability to control infectious \& nutritional diseases, there has come the realization that genetic disorders are a major cause of disability, death \&human tragedy. ${ }^{1}$

About $30 \%$ of all postnatal infant mortality in developed countries is due to genetic diseases, $30 \%$ of pediatric $\& 10 \%$ of adult hospital admissions can be traced predominantly genetic cause. $^{2}$

In Ayurveda there is explanation about beejdosha vikara. Rutu, kshetra, Ambu, Beej ${ }^{3}$ are four things essential for formation of embryo \& its development ${ }^{4}$. The pathological change in any one of stage leads to improper formation of embryo \& its Development. To avoid this scenario the Ayurveda explained the preventive measures as purification therapy \& medicine. So by considering these things a present work has been put forth for the preventive approach for the management of the genetic disorders.

\section{AIM:}

Preventive approach for management of genetic disorder.

\section{OBJECTIVES:}

To study beej dushti in Ayurvedic approach as causative factor in genetic disorder.

To study the causative factor for genetic disorders in present era

\section{BASIC UNIT OF GENETICS-(API) ${ }^{5}$ -}

Deoxyribose nucleic acid (DNA) is a long polymer of nucleotides. Replication of DNA is a key event for transmission of genetic information from parent cell to its progeny. The enzyme helicase \& DNA polymerase are useful for separation of two strands of DNA \& synthesis of DNA respectively. 


\section{TRANSCRIPTION ${ }^{6}-$}

It is the process whereby genetic information stored in DNA is utilized for gene function. It leads to formation of RNA which migrates to cytoplasm for synthesis of protein.

\section{GENETIC CODE ${ }^{7}$ :}

The 20 different amino acids in protein are coded by the four different nucleotides (bases) in DNA. The sequence of triplet nucleotides bases in the DNA molecule that specifies the sequence of amino acids in the protein molecule is called the genetic code.

The human genome refers to the total genetic information in human cell i.e. entire DNA content.

\section{MUTATION ${ }^{8}$ :}

Genetic variations originate from mutation that is defined as a change in DNA sequence that is heritable. Mutations in individual genes are classified on the bases of sequence change $\&$ its consequence on protein product $\&$ its functions.

\section{TYPES OF MUTATIONS ${ }^{9}$ :}

Variation of genomic level- Aneuploidy

Chromosomal level- Tran's location

At gene level- print mutations.

\section{CAUSATIVE FACTORS OF MUTATION:-}

A germ line mutation affects cells that produce gametes and is transmitted from generation to generation, where as somatic mutation is confined to somatic cells ${ }^{10}$.

Most human genetic defects can be categorized as, resulting from either chromosomal ${ }^{11}$ single gene Mendelian $^{12}$, single gene non Mendelian ${ }^{13}$ or multifactorial causes.

The genetic damage also occur from environmental agents such as viruses ${ }^{14}$, plant ${ }^{15}$, fungi $^{16}$, bacteria $^{17}$, industrial chemicals ${ }^{18}$,
Combustion products ${ }^{19}$, alcohol $^{20}$, ultra violate radiation $^{21}$, ionizing radiation $^{22}$, molecular oxygen.

\section{AYURVEDIC VIEW:}

The four components are essential for the formation of embryo viz., rutu, kshetra, ambu, beej $^{23}$.

\section{RUTU: FERTILE PERIOD ${ }^{24}$}

Menstrual period in female i.e. $1^{\text {st }}$ three days are unsuitable for conception $\& 4^{\text {th }}$ day to till end of month are suitable day for conception.

\section{KSHETRA: UTERUS \& PASSAGES ${ }^{25}$.}

It is a place where conception takes place \& embryo grows. Anatomical \& physiological normalcy of organ uterus is important because it is a place where menstruation occurs as well as embryo grows in this cavity.

\section{AMBU: NUTRIENT FLUID ${ }^{26}$}

This concept is closely related to Rasa dhatu which nourishes whole body; also it is important factor for mental condition of human being. Raj \& Stanya are Updhatu of Rasa. Regularity of menstrual cycle depends upon Rasa dhatu.

\section{BEEJ: SPERMATOZOA \& OVUM ${ }^{27,28}$}

Normal or shuddha purush shukra \& stree shonita are essential for formation of normal individual.

Beej is key factor in formation of embryo \& transformation genetic information. Beej is very much essential for transformation of parental characters $^{29}$.

\section{CAUSATIVE FACTORS FOR GARBHA VIKRUTI: ${ }^{30}$}

The beej becomes defective / hampered because of mother diet, unknown reason, time factor, vitiation of dosha. 


\section{IMPACT OF BEEJDUSHTI: ${ }^{31}$}

Which segments of beejavayav get affected, in later stage of development the deformity occurs in that particular organ.

\section{MEASURES TO AVOID BEEJDUSHTI: ${ }^{32,33}$}

In Ayurvedic classics following measures have been told to rectify the beejdushti which is known as beejshodhan.

Snehana swedana

Vamana

Virechan

Madhuroushadhi.

Ghritksheer for male

Tail mash for female

Implication of shodhana therapy after examination of vitiated dosha.

\section{DISCUSSION:}

The genomic phenomenon \& beejdushti phenomenon state that the same pattern that any disturbance or improper arrangement of nucleotide or beejbhag will lead to formation of pathological changes in developing embryo.

The drugs \& procedure elaborated for beejshodhana may helpful to avoid the occurrence of genetic disorder in future generation. The beej shuddhi either may become ray of hope in the management of genetic disorder.

\section{CONCLUSION:}

Genetic disorders \& there pathology is similar to that of beej theory of Ayurveda

The management of beejdushti may be applicable in genetic disorder.

\section{REFERANCES:}

1. http://www.britannica.com/science/disabili ty

2. http://www.britannica.com/science/infantmortility-rate
3. Charak samhitas of Agnivesa edited by vaidya jadavaji trikamaji aacharya, edition 2008, sharirasthana, chapter 2 verse 29, p.n. 305

4. Sushrut samhitas of sushruta edited by vaidya jadavaji trikamaji aacharya, $8^{\text {th }}$ edition 2005, sharirasthana, chapter 2, verse33, p.n. 348

5. API textbook of medicine, yashpal munjal, volume 1 ninth edition, chapter six molecular genetics, human genome project and genomic medicine, p.n. 201

6. API textbook of medicine, yashpal munjal, volume 1 ninth edition, chapter six molecular genetics, human genome project and genomic medicine, p.n. 201

7. API textbook of medicine, yashpal munjal, volume 1 ninth edition, chapter six molecular genetics, human genome project and genomic medicine, p.n. 201

8. API textbook of medicine, yashpal munjal, volume 1 ninth edition, chapter six molecular genetics, human genome project and genomic medicine, p.n. 204

9. API textbook of medicine, yashpal munjal, volume 1 ninth edition, chapter six molecular genetics, human genome project and genomic medicine, p.n. 204

10. API textbook of medicine, yashpal munjal, volume 1 ninth edition, chapter six molecular genetics, human genome project and genomic medicine, p.n. 204

11. http://

www.britannica.com/science/chromosoma 1-disorder

12. http://www.britannica.com/biography/Gre gor-mendel

13. http://www.britannica.com/topic/singelgene-non-mendeline

14. http://www.britannica.com/science/virus

15. http:// www.britannica.com/science/plant

16. http://www.britannica.com/science/fungus

17. http://www.britannica.com/science/bacteri $\underline{\mathrm{a}}$ 
18. http://www.britannica.com/science/mutage $\underline{\mathrm{n}}$

19. http://www.britannica.com/science/combu stion

20. http://www.britannica.com/science/alcohol -consumption

21. http://www.britannica.com/science/ultravi olet-radiation

22. http://www.britannica.com/science/ionisin g-radiation-injury

23. Sushrut samhitas of sushruta edited by vaidya jadavaji trikamaji aacharya, $8^{\text {th }}$ edition 2005, sharirasthana, chapter 2, verse33, p.n. 348

24. Sushrut samhitas of sushruta edited by vaidya jadavaji trikamaji aacharya, $8^{\text {th }}$ edition 2005, sharirasthana, chapter 3, verse 11, p.n. 351

25. Sushrut samhitas of sushruta edited by vaidya jadavaji trikamaji aacharya, $8^{\text {th }}$ edition 2005, sharirasthana, chapter 5, verse 8, p.n. 364

26. Sushrut samhitas of sushruta edited by vaidya jadavaji trikamaji aacharya, $8^{\text {th }}$ edition 2005, sharirasthana, chapter 2, verse33, p.n. 348

27. Charak samhitas of Agnivesa edited by vaidya jadavaji trikamaji aacharya, edition 2008, sharirasthana, chapter 3 verse 3, p.n. 308

28. Sushrut samhitas of sushruta edited by vaidya jadavaji trikamaji aacharya, $8^{\text {th }}$ edition 2005, sharirasthana, chapter 2, verse 33, p.n. 348

29. Charak samhitas of Agnivesa edited by vaidya jadavaji trikamaji aacharya, edition 2008, sharirasthana, chapter 3 verse 3, p.n. 308

30. Charak samhitas of Agnivesa edited by vaidya jadavaji trikamaji aacharya, edition 2008, sharirasthana, chapter 2 verse 29, p.n. 305

31. Charak samhitas of Agnivesa edited by vaidya jadavaji trikamaji aacharya, edition
2008, sharirasthana, chapter 4 verse 30,31, p.n. 321,322

32. Charak samhitas of Agnivesa edited by vaidya jadavaji trikamaji aacharya, edition 2008, chikitsasthana, chapter 30 verse 126, p.n. 640

33. Charak samhitas of Agnivesa edited by vaidya jadavaji trikamaji aacharya, edition 2008, sharirasthana, chapter 8 verse 4, p.n. 340. 